\title{
Arbitragem no Brasil *
}

\author{
Jürgen Samtleben \\ Assessor Científico no Max-Planck-Institut para Direito \\ Privado estrangeiro e internacional, Hamburgo.
}

Quem quiser se informar sobre a arbitragem no Brasil, conta apenas com os relatórios internacionais sobre arbitragem comercial copilados nas diversas coletâneas. Estes relatórios contêm, de um modo geral, uma sinopse sistemática sobre a regulamentação legal do processo arbitral no direito brasileiro e sobre as suas características em particular. Obviamente para o comerciante alemão que negocia com o exterior ou para o seu consultor jurídico estas questões são de importância secundária, visto que para a execução de um processo arbitral no Brasil é aconselhável, de qualquer modo, a participação de um advogado brasileiro. Por outro lado, parece ser mais importante avaliar, de antemão, à luz do direito brasileiro, as chances e os riscos de um processo arbitral brasileiro ou estrangeiro e considerar isto quando da elaboração do contrato. Este estudo pretende oferecer um auxílio neste sentido. Em primeiro plano estão os tratados internacionais celebrados pelo Brasil e sua importância real, a propagação da arbitragem no Brasil, a executoriedade da cláusula de arbitragem, bem como a homologação de sentenças arbitrais estrangeiras. A presente exposição é orientada pela jurisprudência e prática jurídica no Brasil.

\section{Tratados Internacionais}

Tratados internacionais, segundo o direito brasileiro, têm prioridade sobre as leis nacionais ${ }^{1}$. A sua validade interna requer, por um lado, a aprovação do poder legislativo e, por outro lado, a publicação em diário oficial do texto contratual ratificado. Em contrapartida, o direito brasileiro não exige nenhuma lei especial regulamentando

* Tradução direta do alemão pelo professor IRINEU STRENGER, titular de Direito Internacional Privado' na Faculdade de Direito da Universidade de São Paulo. Título original: "Schiedsgerichtsbarkeit in Brasilien".

1. Sup. Trib. Fed., 13-03-1974, Rev. Trim. Jur. 70, pág. 333; 21-08-1951, Rev. Dir. Adm. 34, pág. 106; e ainda 11-10-1943, Arch. Jur. 69, păg. 13 (o voto detalhađo do Juiz Philadelpho Azevedo, pág. 19 e seg.). Da bibliografia: Valladão, Estudos de direito. internacional privado, 1947, pág. 528 seg., 655 e seg., Marotta Rangel, Rev. Fac. Dir. São Paulo 55 (1960) pág. 264 e seg. e outra documentação. 
a execução; com a aprovação parlamentar e a sua publicação, o contrato torna-se, em principio, vinculativo em território nacional ${ }^{2}$.

\section{Acordos Supra-regionais}

a) Protocolo de Genebra sobre cláusulas arbitrais, assinado em 1923

O Brasil é um dos países signatários do Protocolo de Genebra sobre clausulas arbitrais, assinado em 24-9-1923 ${ }^{3}$. Em dezembro de 1929 o governo brasileiro enviou o protocolo ao parlamento que, no entanto, não mais tratou deste assunto ${ }^{4}$. Depois da ascensão ao poder por Getulı Vargas, que governou o país, de 1930 a 1945, quase que exclusivamente sem consuitar o Parlamento, o protocolo foi ratificado pelo Brasil aos 5-2-1932. Quando da ratificação, o Brasil apresentou, segundo art. $1^{\circ}$, par. $2^{\circ}$ do acordo, a ressalva, de que aplicaria o protocolo apenas a assuntos comerciais ${ }^{5}$. A ratificação no Brasil foi publicada, juntamente com o texto do acordo, através do decreto $\mathrm{n}^{\circ} 21.187$ de 22-3-1932, sendo ordenada a sua execução em território nacional ${ }^{6}$. Com relação à República Federal da Alemanha, a reaplicação do Protocolo após a Segunda Guerra Mundial foi expressamente acordada $^{\top}$

Apesar de o Protocolo de Genebra com isto ter-se tornado internacionalmente vinculativo para o Brasil, podem, ainda assim, continuar a existir dúvidas quanto à sua validade nacional. Neste particular o protocolo tem o mesmo destino de outros acordos, ratificados pelo Brasil entre 1930 e 1945, e cuja validade nacional se apresenta problemática por falta de participação do Parlamento. Assim, três das Convenções de Bruxelas sobre direito marítimo de 1924/26 foram ratificadas pelo Brasil em dezembro de 1930 resp. em abril de $1931^{\circ}$. e somente alguns anos mais tarde foram promulgadas no Brasil ${ }^{9}$, com

2. Sup. Trib. Fed., 20-06-1973, Rev. Trim. Jur. 66, pág. 20 ref. ao Convênio relativo à execução de pensão alimentícia firmado em Nova York em 1956; ver também as decisões sob nota 17 mais adiante sobre o direito cambial e de cheques de Genebra.

3. GB1. (Diário Oficial da Alemanha Imperial), 1925 II pág. 47 e seg., 50.

4. O governo havia antes ouvido o parecer de Clóvis Bevilaqua (o autor do Código Civil brasileiro) e consultado a Ordem dos Advogados. Pormenores Valladão em Schönke Kielwein. A Arbitragem em matéria civil e comercial, Vol. 3, 1956, pág. 109, 113 e seg. (Reprodução do Int. Jb. Schiedsg. 1931 pág. 57 e seg.).

5. RGB, (Diário Oficial da Rlemanha Imperial) 1932 II, pág. 131.

6. Coleção das Leis 1932 I, pág. 434. Literalmente: "O Chefe do Governo Provisório da República... decreta que o referido Protocolo, apenso por cópia ao presente decreto, seja executado e cumprido tão inteiramente como nele se contém".

7. BG1. (Diário Oficial Federal), 1953 II, pág. 593.

8. Estas convenções sobre a limitação da responsabilidade de armadores (1924), sobre direitos preferenciais e hipotecas de navios (1924/26) e sobre a imunidade de navios nacionais (1926) haviam sido sancionadas pelo Parlamento diretamente antes da subida ao poder por Getúlio Vargas, Decreto no 5.814 de 14-10-1930, em Novaes de Souza/Costa Faro, Legislação comercial vigente, 1938, pág. 408 seg.

9. Decretos n's 350 - 351 de 01-10-1935 e no 1.126 de 29-09-1936, em Novaes de Souza/Costa Faro, no lugar mencionado, pág. 922 e seg., 1.024 e seg. 
base em uma disposição da Constituição de 1934, que homologava expressamente ${ }^{10}$ todos os atos do "governo provisório". A validade nacional destes tratados permaneceu igualmente duvidosa ${ }^{11}$, sendo, porém, em princípio, confirmada pela jurisprudência ${ }^{12}$. No ano de 1942 o Brasil declarou a sua adesão às convenções de Genebra sobre direito cambial e de cheques de $1930 / 31^{13}$. Neste caso a execução e publicação em território nacional só se realizou vinte anos mais tarde, já sob o Governo de Castello Branco ${ }^{14}$. Este procedimento gerou também uma discussão violenta sobre a aplicabilidade interna dos tratados, principalmente por causa da falta de uma lei especial de execução ${ }^{15}$. Vencendo uma insegurança inicial na jurisprudência ${ }^{16}$, o Supremo Tribunal Federal decidiu este conflito ao determinar que os referidos tratados valem no Brasil como direito diretamente aplicável ${ }^{17}$.

A questão com relação ao Protocolo de Genebra sobre cláusulas arbitrais assinado em 1923 ainda não foi devidamente esclarecida. Este acordo também é considerado por alguns autores como sendo inaplicável, porquanto ainda não tenha sido publicada nenhuma lei executória ${ }^{18}$ a esse respeito ou porque o código de processo civil de 1939 como lex posterior tenha afastado o tratado ${ }^{19}$. Na literatura brasileira, por outro lado, prevalece a opinião de que o protocolo se

10. Veja também Art. 8 das disposições transitórias. Significativamente o presidente se referiu a estas disposições e não à aprovação anterior do Parlamento (veja nota 8).

11. Contrário: Waldemar Ferreira, Tratado de Direito Comercial, Vol. 12, 1964, pág. 392 e seg., Vol. 13, 1964, pág. 695 e seg.; a favor: Hugo Simas, Compêndio de Direito Marítimo Brasileiro, 1938, pág. 114 e seg., 355 e seg.; Castro Rebêlo, Rev. Forense 199 (1962); Somente para casos de divergências internacionais: Stoll Gonçalves, Teoria e prática da avaria comum, 1956, pág. 415 e seg.; Sampaio de Lacerda, Curso de Direito de Navegação, Vol. 1, 1968, Pág. 166 e seg.

12. Com relação à restrição da responsabilidade do armador Sup. Trib. Fed., 30-04-1956, Arch. Jud. 120, pág. 266 (nega objeção ao direito brasileiro); com relação a direitos preferenciais e hipotecas sobre navios Trib. São Paulo, 15-04-1940, Rev. Trib. 131, pág. 154, 169, 188; 23-04-1940, Rev. Trib. 130, págs. 585, 587; Trib. Rio Grande do Sul, 18-09-1940, Rev. Trib. 134, pág. 274, 279 - Rev. Forense 84, pág. 686, 690.

13. Pormenores em Arq. Min. Just. 4 (1943), pág. 92 e seg., 113. Comparar também publicações em Diário Oficial Federal da Alemanha 1970 II, pág. 1.064, 1.075.

14. O Parlamento expressou a sua aprovação através do Direito Legislativo no 54 de 08-09-1964; o texto dos contratos foi publicado pelos decretos no 57.595 e n? 57.663, 24-01-1966.

15. Um bom resumo das diferentes opinióes é dado por Rubens Requião, Rev. Dir. Merc. 1 (1971), pág. 16 e seg.; e ainda Wagner Barreira, Rev. Trib. 429 (1971), pág. 28 e seg. Ver também o parecer do procurador geral na Rev. Trib. 395 (1968) pág. 33 e seg.

16. Ver o sumário sobre jưrisprúdência em Rev. Trib. 419 (1970) pág. 44 e seg. e em Rubens Requião, acima mencionado, pág. 22 e seg. Opinião contrária ainda em Trib. São Paulo, 13-08-1969, Rev. Trib. 406, pág. 182; 23-11-1971, Rev. Trib. 437, pág. 162.

17. Sup. Trib. Fed., 17-05-1968, Rev. Trim. Jur. 68, pág. 76; 10-05 e 04-08-1971, Rev. Trim. Jur. 58, pág. 70 e 744.

18. Assim Garland, American Brazilian Private International Law, 1956, pág. 80, nota rodapé 314 .

19. Comparar contra esta opinião Soares, Rev. Fac. Dir. São Paulo 71, (1976) pág. 188. 
sobrepõe às leis nacionais como direito interno aplicável ${ }^{20}$. $\mathrm{Na}$ verdade pode-se dizer que, baseando-se na jurisprudência acima exposta, o protocolo se tornou direito aplicável em território nacional mediante sua publicação, visto que a falta de participação parlamentar, conforme direito constitucional anterior, pode ser considerada sanada. A jurisprudência mais antiga aceitava, em princípio, a aplicabilidade do protocolo restringindo-a, no entanto, exclusivamente a casos internacionais ${ }^{21}$. Até hoje, todavia, o referido protocolo não alcançou qualquer lugar de destaque na prática forense ${ }^{22}$.

\section{b) Tratado de Genebra sobre a execução de sentenças arbitrais estrangeiras de 1927}

- Tratado de Genebra sobre execução de sentenças arbitrais não foi assinado pelo Brasil. Não obstante, em dezembro de 1929, juntamente com o Protocolo de Genebra de 1923, ele foi submetido ao parlamento brasileiro, mas devido à dissolução deste, não chegou a ser discutido ${ }^{23}$. Nem mais tarde tampouco o Brasil aderiu ao tratado, não sendo, portanto, país signatário ${ }^{24}$.

\section{c) Outros acordos}

O Brasil até hoje ainda não aderiu aos tratados da ONU sobre a homologação e execução de sentenças arbitrais estrangeiras assinados em $1958^{25}$, nem tampouco ao tratado europeu sobre jurisdição arbitral comercial internacional de $1961{ }^{26}$. O Brasil também não participa do tratado do Banco Mundial para dirimir conflitos de investimentos assinado em $1965^{27}$.

20. Valladão, Direito Internacional Privado, Vol. 3, 1978, pág. 212; Barros Leães, Rev. Forense 221 (1968) pág. 424; Dunshee de Abranches, Rev. Forense 228 (1969) pág. 368; Soares (nota de rodapé 19); Marotta Rangel, YB. Com. Arbtr. 3 (1978), pág. 32 seg. Em pormenores Azevedo Mercadante, O protocolo sobre cláusulas arbitrais assinado em Genebra em 1923, em: Tercer curso de derecho internacional organizado por el Comité Jurídico Internacional americano, Washington 1977, pág. 435, 439 e seg.

21. C. Dist. Fed., 18-07-1933, citado em Carvalho Santos, Código civil brasileiro interpretado, Vol. 14, 1936, pág. 25.

22. Comp. Marotta Rangel (nota rodapé 20), pág. 44; Azevedo Mercadante (nota rodapé 20 ), pág. 444, e mais adiante notas 105, 139.

23. Ver acima nota 4.

24. E errada a indicação encontrada no relatório "Brésil" de Frazão Guimarães: Arbitragem international comercial, Vol. 2, Den Haag 1960, pág. 24, que classifica o Brasil como país contratante da, Convention de Genève de 1928 (sic). Parece que o que pretendia dizer era o Protocolo de Genebra de 1923.

25. Os países contratantes da Convenção na América Latina são Equador (1962), México (1971), Cuba (1975), Chile (1975), Colômbia (1979); para a aplicação da convenção nestes paîses consultar a documentação em Samtleben, Rabelsz 44 (1980), pág. 267, nota 55.

26. Dos países latino-americanos apenas Cuba aderiu a este tratado. Samtleben, AWD 19ז1, pág. 215, nota rodapé 10.

27. Sobre a reserva dos países latino-americanos com relação a este tratado com. Pirrung. A arbitragem seg. o acordo do banco mundial para litígios de investimento, 1972, pág. 27, 29; Szosz, Virg. J. Int. L. 11 (1970), pág. 256 e seg., Abbott, Harv. Int. L.J. 17 (1976) pág. 131, 138 e seg. 


\section{Acordos Regionais}

\section{a) o Código Bustamante}

O Brasil é país contratante do Código Bustamante de 1928, um acordo abrangente sobre direito civil, comercial, penal e processual, vigente entre 15 países latino-americanos. As suas disposições só são vinculativas com relação aos países contratantes sendo, porém, às vezes, consultadas com relação a países não-contratantes ${ }^{28}$. O Código Bustamante prevê, em duas passagens, regulamentações sobre a jurisdição arbitral. Segundo os artigos 210-211, tanto a capacidade (competência) arbitral do objeto, como conclusão e efeito do convênio arbitral se orientam pela "ley territorial", que aqui significa a lex fori ${ }^{29}$. Além disso o art. 432 determina que as disposiçôes do Código Bustamante sobre homologação mútua e execução de decisões também se aplicam às sentenças arbitrais promulgadas em um país contratante, na medida em que o objeto seja arbitrável segundo o direito do país de execução ${ }^{30}$. Enquanto estas disposições freqüentemente desempenham um papel importante na prática latino-americana ${ }^{31}$ no que diz respeito à homologação de decisões judiciais estrangeiras, não é possivel constatar uma influência análoga no Brasil quanto a sentenças arbitrais estrangeiras ${ }^{32}$.

\section{b) Convenções interamericanas $1975 / 79$}

A Convenção Interamericana sobre arbitragem comercial internacional, assinada no Panamá em 1975, já vigora entre oito países latino-americanos ${ }^{33}$. Ela contém disposições mais detalhadas sobre a validade de cláusulas arbitrais no intercâmbio comercial internacional e sobre a execução de decisões arbitrais estrangeiras. Apesar de a Convenção não o mencionar expressamente, a sua aplicação deve pressupor que as partes contratantes tenham a sua sede em diferentes países contratantes ${ }^{34}$. O Brasil assinou a convenção, porém ainda não a ratificou.

28. Ver Samtleben, Direito Internacional Privado na América Latina, Vol. 1, 1979, pág. 57 e seg., 138 e seg., 158 e seg., para o Brasil, pág. 286 e seg.

29. Comparar Bustamante y Sirvén, Derecho Internacinal Privado. Vol. 2, 1931, no 1.248 e seg., 1.254 e seg. Por outro lado, para a competência arbitral privada vale, segundo a concepção de Bustamante, o estatuto do pessoal, idem n' 1.250.

30. A disposição prevê apenas que o local do processo de arbitragem esteja situado em um país contratante, independente das partes participantes, comparar Samtleben (nota de rodapé 28), pág. 149 nota de rodapé 130.

31. Exemplos em Samtleben (nota de rodapé 28), pág. 155 e seg.

32. Comparar Rosenn, Am. J. Comp. L. 28 (1980) pág. 504: "Since ... there has traditionally been considerable reluctance to reesort to arbitration in Latin American countries, it is not surprising that art. 432 has apparently never been invoked in Brazil"

33. Ver Samtleben, Rabelsz (1980) pág. 265 e seg. Países contratantes são o Chile, Costa Rica, Honduras, México, Panamá, Paraguai, Salvador e Uruguai. Os Estados Unidos, ao contrário do que informa Rosenn (nota de rodapé 32), não ratificaram a convenção até hoje (informação do OAS de 06-11-1980).

34. Samtleben, Rabelsz 44 (1980) pág. 317. 
Instruções complementares estão contidas na Convenção Interamericana sobre o efeito extraterritorial de sentenças e decisões arbitrais estrangeiras, assinada em Montevidéu em $1979^{35}$. As suas disposições devem ser aplicadas, segundo art. $1^{\circ} \S 2^{\circ}$, a decisões arbitrais, contanto que a convenção do Panamá de 1975 não contenha nenhuma regulamentação. O Brasil assinou a Convenção de Montevidéu - com reserva não tendo, porém, ratificado ainda ${ }^{36}$. $\mathrm{Na}$ praxe mais recen temente adotada pelo Supremo Tribunal Federal brasileiro já se fez referência aos fundamentos desta convenção ${ }^{37}$ para a homologação de uma decisão arbitral de Hamburgo.

\section{Direito Nacional}

\section{Fundamentos jurídicos}

Desde os tempos da colonização portuguesa ${ }^{38}$ a arbitragem é legalmente reconhecida no Brasil. Sob a legislação brasileira posterior, ela sofreu várias reformulações novas, encontrando atualmente seu fundamento jurídico em diversas leis.

\section{a) Direito constitucional}

Já a primeira Constituição brasileira de 1824 previa em seu art. 160 que divergências jurídicas civis fossem decididas por árbitros nomeados pelas partes. Apesar de não se encontrar nenhuma instrução pertinente nas Constituições seguintes, a competência dos tribunais de arbitragem se mantinha incontestável. A Constituição de 1934 até se referia à arbitragem comercial entre os objetos da legislação federal (Art. 5, XIX, c). A Constituição de 1946 previa, pela primeira vez, uma garantia expressa da via judicial, também assumida pela Constituição vigente de $1969{ }^{39}$. Esta disposição representava uma reação contra as restrições impostas aos tribunais sob o Governo Getúlio Vargas e não visava a arbitragem ${ }^{40}$; na literatura, no entanto, foi várias vezes interpretada neste sentido ${ }^{41}$. Todavia, a jurispru-

35. Samtleben, RabelsZ 44 (1980) pág. 299 e seg. A convenção foi ratificada até hoje

36. A reserva brasileira se refere ao art. 2 lit. d) da Convenção, segundo o qual legislação interna (direito) do segundo pais (ver também nota de rodapé 120 adiante). A competéncia judiciária internacional do primeiro país deve ser analisada à luz da pelo Peru e Urugiai.

37. Ver adiante nota de rodapé 145.

38. Ordenações Filipinas (1963) Livro III, Título 16. Ver também no Brasil Moraes Carvalho, Praxe forense, 1850, pág. 44 e seg.

39. Constituição de 1946, art. $141 \S 4=$ Constituição de 1967, art. $150 \S=$ Constituição de 1969 , art. $153 \S 4$.

40. Comparar Sampaio Dória, Direito Constitucional, Comentários à constituição de 1946, Volume 3, 1960, pág. 599 e seg.

41. Ainda em Mendonça Lima, Rev. Trib. 402 (1969) pág. 9 e seg. $=$ Rev. Forense 227 (1969) pág. 381 e seg. De outra opinião são Oliveira Filho, Rev. Forense 122 (1949) pág. 615; Carvalho Santos, Rev. Forense 164 (1956) pág. 115 e seg.; Pontes de Miranda, Comentários ao Código de Processo Civil, vol. 15, 1962, pág. 144. 
dência por várias vezes deixou bem claro que esta disposição não entra em conflito com o acordo de um tribunal de arbitragem ${ }^{42}$. Da mesma forma o Estado pode, em conformidade com isto, se submeter à decisão de um tribunal de arbitragem ${ }^{43}$, exceto em se tratando de sua atividade soberana ${ }^{44}$.

\section{b) Código Civil}

$\mathrm{O}$ fundamento jurídico decisivo para o contrato de arbitragem encontra-se ainda hoje no Art. 1037 e seguintes do Código Civil de 1916. De acordo com o mesmo, as partes podem, mediante um contrato de arbitragem, acordar em submeter as suas divergências juridicas à decisão por um tribunal de arbitragem, contanto que possuam a capacidade de celebrar contratos (Art. 1037) ${ }^{45}$. O contrato arbitral em um litígio pendente pode ser concluído mediante protocolo lavrado em juízo ou então mediante um instrumento público ou privado, assinado pelas partes e por duas testemunhas (Art. 1038) ${ }^{46}$. Deve especificar o objeto do litígio bem como os árbitros escolhidos e seus prepostos (Art. 1039). Disposições mais detalhadas sobre o conteúdo do contrato de arbitragem e sobre o processo arbitral estão contidas nos arts. 1040-1047, que foram em parte modificados pelos códigos de processo civil posteriores (veja $d$ mais adiante). Além disso encontram aplicação análoga as disposições referentes à transação; um contrato arbitral é pois somente admissível com relação a divergências sobre direitos patrimoniais de natureza privada (art. 1035, 1048) ${ }^{47}$.

\section{c) Direito Comercial}

O processo arbitral obrigatório para assuntos comerciais, adotado pelo Código Comercial de 1850 com base no modelo francês, já em

42. Trib. Dist. Fed. 29-01-1952, Repertório enciclopédico do direito brasileiro, Vol. 30, pág. 42; 'Trib. São Paulo, 27-08-1953, Rev. Trib. 217, pág. 233; 17-12-1959, Rev. Trib. 296, pág.410. Enquanto estas decisões ainda exigem a possibilidade de um exame judicial, o Supremo Trib. Federal considera uma exclusão legal de qualquer exame posterior como compativel com o Direito Constitucional, Sup. Trib. Fed., 15-11-1973, Rev. Trim. Jur. 68, pág. 382, 392 e seg., 396.

43. Sup. Trib. Fed., 13-06-1969, Rev. Trim. Jur. 52, pág. 168, 171 e seg.; em pormenores 14-11-9i3, Rev. Trim. Jur. 68, pág. 382, 384, 391 e seg.

44. Ver Sup. Trib. Fed., 16-06-1942, Rev. Trib. 142, pág. 774 (com relação a dívidas fiscais); e ademais o parecer do Ministério dos Transportes na Rev. Forense 95 (1943) pág. 56 (ref. a medidas monetárias). Comparar também Pontes de Miranda (nota 41) pág. 160 e nota 47 adiante.

45. Para menores de idade os pais s6 poderảo concluir um contrato arbitral com autorização judicial. Trib. Minas Gerais, 26-06-1926, Rev. Forense 47, pág. 715; um contrato arbitral sobre cotas de herança (a partilha) de menores é inadmissivel. Trib. São Paulo, 21-08-1941, Rev. Trib. 135, pág. 157.

46. Trib. São Paulo, 19-06-1939, Rev. Trib. 121, pág. 201; é possível lavrar-se um auto em juízo, também fora de um litígio, sem testemunhas; Trib. Guanabara, 01-06-1962, Rev. Trib. Guanabara 2, pág. 226: contrato de arbitragem privado por escrito é nulo sem testemunhas. - Sobre o regulamento de um processo arbitral do testamento ver, por um lado, Carvalho Santos (nota 21), pág. 28 e seg.; por outro lado Pontes de Miranda (nota 41), pág. 145 e nota 56 adiante.

47. Sup. Trib. Fed, 29-09-1942, Brasil-Acórdãos, Nova Série, 19 suplemento, Vol. 2. (1949) pág. 90. 
1866 era abolido novamente ${ }^{48}$ e, com o Decreto $n^{\circ} 3.900$ de 1867 , a jurisdição arbitral comercial sofreu nova regulamentação. De importância capital para a evolução da doutrina do direito foi o Art. $9^{\circ}$ do decreto, segundo o qual uma cláusula arbitral sobre litígios futuros só possui valor de promessa (veja, II, 3 adiante). O decreto também permaneceu em vigor ao lado do Código Civil e somente paulatinamente foi sendo substituído pelas leis processuais ulteriores de cada Estado e da Federação ${ }^{49}$. A jurisdição arbitral obrigatória prevista para certas operações comerciais por leis estaduais, era considerada anticonstitucional ${ }^{50}$. Da mesma forma, no direito marítimo, uma regularização forçada, por meio de árbitros, está fora de cogitação; a disposição pertinente contida no Art. 783 do Código Comercial, portanto, não é mais obrigatória ${ }^{51}$. No Direito Comercial vigente não existe mais nenhuma regulamentação especial no que se refira diretamente à jurisdição arbitral. Em parte, porém, tal regulamentação é derivada da Lei das Sociedades Anônimas de $1976{ }^{52}$.

\section{d) Direito Processual}

O processo arbitral, que até recentemente esteve incluído nos diferentes códigos processuais da Federação e de cada Estado, sofreu, pela primeira vez, regulamentação uniforme no Código de Processo Civil de $1939{ }^{53}$. No Código de Processo Civil vigente de 1973, o capítulo pertinente foi novamente redigido ${ }^{54}$. Os artigos 1072-1077 contêm instruçōes sobre o contrato de arbitragem, as quais repetem as disposições do Código Civil, complementando-as parcialmente (veja $b$ acima). Os artigos 1078-1084 seguintes fixam disposições mais detalhadas sobre

48. Comparar Araújo Costa, Codigo Commercial do Império do Brazil, $3^{\text {a }}$ edição, 18ir8, pág. 498, 619 e seg., 985 e seg., Gonçalves do Couto, Do juízo arbitral. 1920, pág. 16 e seg. - Sobre a inaplicabilidade das disposições pertinentes do Código Comercial ver ainda Trib. São Paulo, 18-11-1925, Rev. Trib. 56, pág. 435, e nota 51 adiante.

49. Comparar pormenorizadamente Bento de Faria, Código commercial brasileiro. Vol. 2, 39 edição, 1920, pág. 7 e seg., 205; Gonçalves do Couto (nota 48), pág. 51 e seg.; Novaes de Souza/Costa Faro (nota 8), pág. 31; Costa Carvalho, Rev. Trib. 196 (1937) pág. 16 e seg.; Valladão (nota 4) pág. 109 e seg.

50. Por exemplo a Lei ne 1.416 da Estado de São Paulo de 14-07-1914, que prescrevia para operações na bolsa a prazo um processo arbitral obrigatório; comparar com j: risprudência Costa e Silva, Rev. Trib. 36 (1920) pág. 185 e seg.

51. Sup. Trib. Fed., 06-04-1918 e 19-05-1923, Rev. Sup. Trib. 17, pág. 61, 247 e 56, pág. 108. Cláusulas de conhecimento pertinentes são consideradas sem efeito legal e a regulamentação usual por despachantes apenas como um parecer de peritos; Stoill Gonçalves (nota 11), pág. 300 .

52. Esta lei permite no art. 118 \& 3 quando de ajustes entre acionistas de acordo com o modelo norte-americano, a "execução especifica" (specific performance); donde se infere que as cláusulas de arbitragem contidas nesses ajustes são exeqüíveis judicialmente, Marotta Rangel (nota 20), pág. 32 .

53. Ver art. 1.031-1.046 e com relação ao direito anterior as comprovações acima, na nota 49, principalmente com relação ao projeto do código processual civil Costa Carvalho (nota 49). é seg.

54. Comparar aqui a visão geral abrangente em Marotta Rangel, (nota 20), pág. 33 
os árbitros ${ }^{55}$. A antiga regulamentação, segundo a qual estrangeiros não podiam ser árbitros, foi eliminada ${ }^{56}$. Os artigos 1085-1096 regulam o procedimento do processo arbitral e a lavratura do laudo arbitral ${ }^{57}$. A sentença arbitral exige, para que produza efeito, a homologação (confirmação judicial); neste procedimento verifica-se se ela atende a certos requisitos legais (artigos 1097-1100) ${ }^{58}$. Contra a decisão judicial é possível apresentar recurso (artigos 1101-1102). O recurso não pode ser excluído pelo contrato arbitral; porém, na hipótese de se negar provimento à apelação, pode ser acordada uma pena convencional (art. 1101, § 10)59. Da mesma forma, a jurisprudência confirmou a possibilidade da ação recisória ${ }^{60}$. A execução da sentença arbitral homologada é realizada em processo executório normal pelo tribunal de direito comum ${ }^{61}$.

\section{Prática}

Nas exposições gerais sobre jurisdição arbitral no Brasil afirma-se, via de regra, que a arbitragem, na prática, mal alcançou algum signi-

55. imprescindivel que o número de árbitros seja sempre impar, art. 1.076; comparar para o caso de igualdade de votos ainda Trib. São Paulo, 22-10-1964, Rev. Trib. 374, pág. 1 ז́6.

56. Comp. ainda art. 1.031 do Código de Processo Civil 1939. - Como árbitro pode ser nomeado um juiz, mas não um tribunal em si; uma cláusula arbitral em rm testamento foi considerada nula somente por este motivo, Trib. São Paulo, 02-12-1952, Rev. Trib. 208, pág. 194.

57. Detalhes em Marotta Rangel (nota 20), pág. 37 e seg. O laudo arbitral deve ser promulgado dentro do prazo acordado (ou legal), art. 1.077 III (artigos 1.091, 1.093): para a cálculo do prazo ver Trib. São Paulo, 19-06-1939 (nota 46) e 11-12-1956, Rev. Trib. 260, pág. 347 .

58. Ver cm relação ao procedimento e extensão do controle: Trib. Rio de Janeiro, 26-06-1975, Rev. Trib. 481, pág. 19، (nenhum exame de matéria); Trib. São Pa lo, 16-05-1978, Rev. Trib. 514, pág. 82 (nulidade do contrato arbitral, vícios de processo) - Comp. também com relação ao direito anterior: Trib. Dist. Fed., 21-11-1952, Rev. Forense 150, pág. 236 (exame judicial limitado); Trib. São Paulo 29-03-1913, Rev. Trib. 5, pág. 270 (decisão equitativa); 09-11-1954, Rev. Trib. 232, pág. 162 (transcendência do contrato arbitral); e ainda as decisões acima, nota 42.

59. Já com. os artigos 1.046-47 do Código de Processo Civil, além da jurisprudência da C. Suprema, 02.05-1918, Brasil-Acórdãos Vol. 7 (1935) no 19.221; C. Dist. Fed., 09-05-1912, Rev. Dir. 25, pág. 310 (embargos de terceiros); Trib. Minas Gerais, 09-07-1938, Rev. Forense 76, pág. 347 (prestação de caução); Trib. Guanabara 01-06-1962 (nota 46); Trib. São Paulo, 16-05-1978 Rev. Trib. 514, pág. 82 (valor da multa contratual); com relação ao direito mais antigo Sup. Fed., 06-05-1905, O Direito 101, pág. 243 com provas.

60. Sup. Trib. Fed., 21-10-1940, Rev. Trib. 137, pág. 332: O trib nal de direito comum decide sobre a ação rescisória contra a sentença arbitral (por violação do teor da lei). Opinião diferente é representada por Pontes de Miranda (nota de rodapé 41) pág. 142, que considera como objeto da apelação da sentença apenas a homologação do laudo arbitral.

61. Ver Sup. Trib. Fed. 29-09-1920, Rev. Forense 37, pág. 52; Trib. Dist. Fed. 14-11-1944, Rev. Trib. 158, pág. 803. Em contraposição ao art. 1.045 do C6digo Civil, de acordo com o Direito Processual vigente, mesmo o laudo arbitral proferido por um juiz só pode ser executado após a homologação judicial, comp. Trib. São Paulo, 28-10-1952, Rev. Trib. 207, pág. 130 (diferente da decisão da nota anterior). Convenções voluntárias sobre o cumprimento da sentença arbitral não necessitam de homologação judicial, Trib. Dist. Fed., 29-06-1955, Arch. Jud. 115, pág. 303. 
ficado ${ }^{62}$. Como argumentação costuma-se citar geralmente a tradicional aversão contra este procedimento de resolver litígios e, principalmente, a falta de comprometimento da cláusula arbitral (veja, II, 3 , adiante). Um estudo preciso fornece obviamente um quadro mais diferenciado.

\section{a) Prática contratual}

O acordo sobre resolução arbitral de litígios não é fenômeno raro na realidade jurídica brasileira, haja vista a extensa jurisprudência referente a essas questões. Assim já se encontram, no passado, convenções de arbitragem, principalmente em contratos celebrados por municípios e cidades com companhias de utilidade pública, muitas vezes apoiadas por empresas estrangeiras. Além disso surgem, com freqüência, entidades estaduais como parceiros de convenções de arbitragem, casos estes em que é considerada necessária uma autorização legal ${ }^{63}$. A Lei $n^{\circ}$ 1.628 de 29-6-1952 sobre o Banco Nacional de Desenvolvimento, por exemplo, contém, mutatis mutandis, uma autorização análoga ${ }^{64}$. Também para transações comerciais no Brasil recorre-se freqüentemente a convenções de arbitragem; especialmente em contratos sociais são inseridas, às vezes, cláusulas correspondentes ${ }^{65}$. É muito comum acordarem-se cláusulas de arbitragem nas relações comerciais internacionais, quando diferentes formas são empregadas ${ }^{66}$. Todavia, na prática cautelar, antes procura-se desaconselhar o emprego dessas cláusulas, sobretudo tendo em vista o fato de a homologação de decisões arbitrais estrangeiras no Brasil até agora aparentemente não estar garantida ${ }^{67}$. Quanto a este ponto, porém, houve, nesse ínterim, modificação que irá influenciar também a prática futura (ver, II, 4, adiante).

62. Valladão (nota 4), pág. 109, 112 e seg.; Garland (nota 18), pág. 79 e seg.; Marotta Rangel (nota 20), pág. 31; Miranda Rosa, (Relatório sobre o Brasil, Kopenhagen 1975), Rev. Forense 254 (1976), pág. 479; Gusmão Carneiro em "Tribuna da Justiça", São Paulo, de 05-11-1980.

63. Comp. Sup. Trib. Feđ. 14-11-19:3 (nota 42) pág. 392; similar já no C. Dist. Fed. 20-11-1905, Fev. Forense 5, pág. 45: outros dados sobre a prática mais ađiante na nota 70 e seg. - Com relação a um contrato arbitral entre a Western Telegraph Company Ltd. e o Ministério dos Transportes, ver o aviso da autoridade tributária em Revista Fiscal 8 (1937), Imposto do sello ne 110.

64. De acordo com o art. 23 desta lei o Tesouro Nacional pode pactar validamente a arbitragem diretamente ou através do Banco de Desenvolvimento quando de operações financeiras internacionais, também para litígios futuros, ver ađiante nota 103.

65. Comp. Ascarelli/Sciascia, Arbitr. J. 5 (1950) pág. 206.

66. Uma sinopse sobre as cláusılas mais comuns a favor de tribunais arbitrais brasileiros ou estrangeiros é dada por Dunshee de Abranches (nota 20), pág. 386; costuma-se reportar também às normas do IHKK Paris, ver Barros Leães (nota 20), pág. 426; em geral para contratos de empréstimos internacionais consultar Salles, Rev. Forense 256 (1976) pág. 43. Sobre o caso de uma cláusula de arbitragem em um contrato consorcial teutobrasileiro existem dados pormenorizados em Moser, Questões do direito comercial latino-americano, 1966, pág. 33 e seg.

67. Ver talvez Coriat, Transfert de technologie au Brésil, Droit prat. com. int. 6 (1980) pág. 273 e seg., 278; Sodré de Carvalho/Owers, Dragting Contracts Nnder Brazilian Law, Int. Lawyer 14 (1980) pág. 115 e seg., 121. 


\section{b) Prática arbitral}

No Brasil, assim como em outros países, decisões arbitrais só raramente são publicadas; até hoje apenas ocorreu em alguns casos espetaculares. Por volta do início deste século, o caso "Dr. Werneck v. Minas Gerais", tendo como objeto o arrendamento ${ }^{68}$ de uma estação terminal inteira, ganhou grande notoriedade. Mais recentemente ficou conhecido o caso "Companhia Siderúrgica Nacional v. Batista Pereira", que tratava da exploração de uma mina de carvão no Estado de Santa Catarina ${ }^{69}$. Além disso, em vários casos, entidades governamentais integraram processos de arbitragem com base nos já referidos contratos assinados com empresas de utilidade pública locais, sem recorrer à não-obrigatoriedade da cláusula arbitral ${ }^{70}$. Outros processos arbitrais se referiam a pagamentos de indenização do Estado devida por valores patrimoniais confiscados ${ }^{71}$. Também entre pessoas privadas está se tornando cada vez mais comum a realização de processos de arbitragem, conforme pode ser depreendido de jurisprudência concernente. Nestes casos o objeto do processo arbitral raramente é citado, estando ligado, porém, na maioria dos casos, a transações comerciais ${ }^{72}$.

\section{c) Instituições}

No Brasil sempre foram envidados esforços visando apoiar a arbitragem, principalmente no âmbito das transações comerciais, constituindo-se instituições adequadas ${ }^{73}$. Só recentemente foram alcançados

68. Sentença arbitral de 13-03-1916, Rev. Forense 25 (1916) pág. 307-347; ver o laudo judicial, idem, 27 (1917) pág. 229-240 bem como as decisões do Supremo Trib-nal de 08-08-1917, Rev. Sup. Trib. 13, pág. 52, e de 20-04 e 25-05-1918, Rev. Dir. 51, pág. 426 e 537.

69. Sentença arbitral de 15-01-1952, Rev. Forense 150 (1953) pág. 239-247; e Trib. Fed. 21-11-1952 (nota 58).

70. Comparar a sentença arbitral "Prefeito de Belo Horizonte v. Companhia de Eletricidade" de 12-0\%-1915, Rev. Forense 24, pág. 271-215; para validade com relação a terceiros Trib. Minas Gerais, 23-05 e 14-11-1917, Rev. Forense 29, pág. 175 . Além disso, no caso “The Rio de Janeiro City Improvements Co. v. Governo Federal” o douto parecer de Levi Carneiro em: Pareceres do Consultor Geral da República 1931-32, Vol. 3, 1954, pág. 75 e seg. Ver também os casos concernentes em Rev. Trib. 36 (1920) pág. $24 ; 142$ (1943) pág. 774; 207 (1953) pág. 130; 217 (1953) pág. 233; 232 (1955) pág. 162; 346 (1964) pág. 442; além de Gonçalves do Couto (nota 48), pág. 34 e seg., 123 e seg.

71. Um processo arbitral desse tipo sobre bens confiscados durante a guerra da "Organização Lage" foi objeto da decisão do Supremo Tribunal Federal 14-11-1973 nota acima 42); com relação a um processo arbitral ao invés do confisco formal ver Trib. Minas Gerais, 09-01-1938 (nota 59). Comp. também Sup. Trib. Fed. 21-10-1940, Rev. Trib. 137, pág. 332 (privação da concessão de loteria).

72. Comp. da praxe forense mais antiga uma sentença arbitral de 1907, Rev. Forense 10, pág. 370 (aval de letra); além disso Trib. São Paulo, 10.02-1925, Rev. Trib. 53, pág. 235 (contrato social); 19-06-1939, Rev. Trib. 121, pág. 201 (contrato sobre fornecimento de madeira); C. Dist. Fed. 07-09-1926, Rev. Dir. 83, pág. 355 (contrato de seguro); Trib. Dist. Fed. 14-11-1944, Rev. Trib. 158 pág. 803 (direito de hipoteca e cambial); 29-06-1955, Arch. Jud. 115, pág. 308 (contrato de distribuição exclusiva de trigo norte-americano); com relação à praxe forense mais recente ver também Carvalho Santos (nota 41). - Sobre direito marítimo ver nota 51 supra.

73. Ver Arruda, Rev. Trib. 40 (1921) pág. 96 e seg.; Valladão (nota 4), pág. 112 e seg.; Dunshe de Abranches (nota 20), pág. 386. Um projeto de lei oficial de 1951 previa a instituição de um órgão de arbitragem de comércio exterior; comp. em Rev. Dir. Merc. 1 (1951 pág. 831 e seg. 
resultados palpáveis, para os quais a atividade da Inter-American Commercial Arbitration Commission (IACAC) concorreu de forma decisiva ${ }^{74}$. No ano de 1967 foi fundado o Centro Brasileiro de Arbitragem, com sede no Rio de Janeiro, e que funciona como instituição de arbitragem permanente e, ao mesmo tempo, como seção regional do IACAC ${ }^{75}$.

Endereço: Centro Brasileiro de Arbitragem

Avenida Franklin Roosevelt, 23, Grupo 808

Rio de Janeiro, Brasil

Além disso, no ano de 1979, dentro da estrutura da Câmara de Comércio Brasil-Canadá em São Paulo, foi constituída uma instituição de arbitragem permanente, especialmente para tratar de assuntos comerciais internacionais. O seu campo de ação não se limita apenas ao intercâmbio comercial Brasil-Canadá, estando aberto a outras nações. Para árbitros foram escolhidos professores e advogados brasileiros ${ }^{76}$.

Endereço: Câmara de Comércio Brasil-Canadá

Avenida Brigadeiro Faria Lima, 1058

São Paulo, Brasil

\section{Cláusula arbitral}

O presente estudo demonstra que cláusulas arbitrais são comuns na prática brasileira e, na verdade, freqüentemente conduzem a um processo arbitral. O significado legal de tais cláusulas, no entanto, sempre foi bastante controvertido ${ }^{77}$ A opinião geral que até hoje predomina na literatura, é de que estas cláusulas contêm meramente um compromisso civil, cujo inadimplento pode provocar pretensões de indenização, não justificando, porém, qualquer exceção (objeção) perante o tribunal ordinário. Por outro lado, uma execução coercitiva (forçada) da cláusula arbitral mediante uma exceção deste tipo e, eventualmente, uma constituição judicial dos árbitros, só raramente foi considerada admissível ${ }^{78}$. $\mathrm{Na}$ jurisprudência a cláusula muitas vezes é até declarada como totalmente sem efeito e considerada sem qualquer importância.

74. Sobre a história e experiência da IACAC ver Samtleben, Rabelsz 44 (1980) pág. 266 com mais provas. - Os regulamentos processuais vigentes da IACAC se encontram no YB. Com. Arbitr. 3 (1978) pág. 231 e segs., lá também a cláusula de arbitragem recomendada.

75. Comp. Soares (nota 19), pág. 194 e seg.; Marotta Rangel (nota 20), pág. 31 e seg.

76. Ver Pinheiro Neto \& Cia., Lawyer of the Americas 12 (1980) pág. 252.

77. Ver Dunshee de Abranches (nota 20), pág. 384; R. Nunes, Rev. Trib. 284 (1959) pág. 12, 15 e seg. Um bom resumo encontra-se nas seguintes decisões: C. Minas Gerais, 18-11-1936, Rev. Forense 69, pág. 116; T. Alç. São Paulo, 07-03-1978, Rev. Trib. 512, pág. 170.

78. Principalmente Mendes Pimentel em seu estı:do amplamente citado: "Da cláusula compromisśria no direito brasileiro", 1934. - Um regulamento pertinente já se encontrava incluído no projeto de um código de processo civil para o distrito federal de 1910, comp. Valladão (nota 4), pág. 111; Gonçalves do Couto (nota 48), pág. 93. 


\section{a) Casos nacionais}

A evolução do direito brasileiro foi profundamente influenciada pelo já mencionado Decreto $n^{\circ} 3.900$ de 1867 , cujo art. $9^{\circ}$ caracterizava claramente a cláusula de arbitragem ref. a litígios futuros como uma mera promessa. Já a jurisprudência do século XIX levava à conclusão de que uma tal cláusula não poderia excluir os trâmites legais normais ${ }^{79}$. A mesma concepção orientava também as disposições do Código Civil de 1916, que regulamentava apenas o contrato de arbitragem com relação a litígios existentes e seus requisitos formais ${ }^{80}$. Baseando-se nestas instruções e no Decreto $n^{\circ} 3.900$, que continuavam em vigor, a jurisprudência decidiu, salvo algumas exceções, não permitir a exceção de arbitragem com base em uma simples cláusula de arbitragem ${ }^{81}$. Importância particular alcançou a decisão do Supremo Tribunal Federal no caso "Alves Medeiros \& Co. v. Lloyd Industrial Sul Americano", que declarou uma cláusula de arbitragem em um contrato de seguro marítimo absolutamente sem efeito ${ }^{82}$. Esta decisão foi seguida pela jurisprudência dos tribunais inferiores ${ }^{83}$, onde decisões individuais procuram adicionalmente provar que, mesmo válida a cláusula, esta não abrange o litígio $^{84} \mathrm{ou}$, pelo menos, não permite nenhuma exceção ${ }^{85}$.

79. J. Bahia, 13-08-1889, O Direito 51, pág. 234 (contrato social); Trib. São Paulo, 03-12-1896, Brasil-Acórdãos Vol. 7 (1936) ne 19.226.

80. O autor do Código Civil declarou em seus comentários que a cláusula arbitral não fundamenta nenhuma exclusão process cal mas apenas uma obrigação civil com (conseqưuencia de) indenização; Clóvis Bevilaqua, Código Civil, Reimpressão 1979, Art. 1.037 Obs. 3.

81. C. Dist. Fed. 20-04-1920, Rev. Dir. 56, pág. 530 (contrato social); 15-09-1922, idem 69, pág. 336 (contrato social); J. Dist. Fed. 18-01-192؟, idem 83, pág. 389 (contrato de construção por empreitada); Trib. São Paulo, 10-04-1924, Rev. Trib. 50, pág. 111 (contrato de construção por empreitada); 11-12-1924, idem 53, 31; J. São Paulo, 01-12-1923, idem 48, pág. 534 (nenhuma ação para celebração do contrato arbitral); ver também os pareceres jurídicos em Rev. Dir. 50 (1918) pág. 467 e seg., Rev. Forense 47 (1926) pág. 282 e seg., Pandectas Brasileiras 2, 1927, II, pág. 458 e seg. - Difere J. Dist. Fed. 26-08-1922, Rev. Forense 40, pág. 397 (contrato social); divergente também C. Dist. Fed. 10-07-1925, Rev. crit. jud. 1925, pág. 236 (contrato de seguro); Trib. São Paulo, 10-02-1925 (nota 72).

82. Sup. Trib. Fed., 24-08-1927, Arch. Jud. 3, 50氵 $=$ Rev. Dir. 85, pág. $425=$ Rev. Forense 49 , pág. $387=$ Rev. Jur. Bras. 13, pág. 174; igualmente em um outro caso de seguro marítimo 07-10-1931, idem 15, pág. 41.

83. Trib. São Paulo, 26-07-1928, Rev. Trib. 72, pág. 104; 27-11-1931, idem 81, pág. 97 (contrato de concessão); 03-08-1934, idem 94, pág. 542 (contrato de licença), com parecer Lacerda pág. 356 e seg.; 22-09-1937, idem 112, pág. 530 (contrato de construção de ruas) com comprovações detalhadas; 09-02-1938 idem, pág. 584 (contrato social); Trib. Rio Grande do Sul, 02-12-1940, Arch. Jud. 58, pág. 53 (contrato de arrendamento); igualmente C. Minas Gerais, 18-11-1936, Rev. Forense 69, pág. 116 (contrato de concessão) com voto de Orozimbo Nonato.

84. C. Dist. Fed. 27-05-1929, Rev. Dir. 94, pág. 331: a cláusula, que "de preferência" um tribunal de arbitragem deveria decidir, representa apenas uma possibilidade de opção; 22-06-1936, Rev. Forense 67, pág. 72 i: cláusula arbitral em contrato social só vale para a ađministração vigente, não no caso de dissolução; Trib. Dist. Fed. 27-07-1943, Rev. Dir. 147, pág. 314; cláusula de arbitragem com relação à interpretação de contrato não vale para inadimplento.

85. Trib. São Paulo, 03-02-1931, Rev. Trib. 77, pág. 320: outros efeitos não excluídos; Trib. Dist. Fed. 03-11-1939, idem 131, pág. 707: a cláusula arbitral prevê apenas multa contratual. 
Com a regulamentação uniforme do Direito Processual Civil pelo Código de Processo Civil de 1939, o Decreto n*3.900 foi definitivamente abolido ${ }^{86}$. Na verdade, algumas decisões individuais que se seguiram, consideraram a exceção de incompetência (declinatória de competência judıciaria) como admissível, com base na cláusula de arbitragem ${ }^{87}$. A maior parte da jurisprudência, porém, optou pela concepção reinante até agora, continuando a declarar a cláusula de arbitragem de efeito nulo ${ }^{88}$ ou, no máximo, obrigatória do ponto de vista civil ${ }^{89}$. O Código de Processo Civil de 1973 levou em conta esta evolução, permitindo a exceção arbitral apenas com base em um contrato de arbitragem formal (Art. 301 IX) ${ }^{90}$. Em contrapartida, a questão referente aos demais efeitos da cláusula de arbitragem ainda não foi definitivamente esclarecida.

\section{b) Casos internacionais}

$\mathrm{Na}$ literatura brasileira encontra-se, às vezes, a opinião de que a validade (eficácia) da cláusula de arbitragem em contratos internacionais seria regida pelo estatuto contratual e, com isso, eventualmente, por direito estrangeiro ${ }^{91}$. A jurisprudência, porém, julga tais cláusulas de arbitragem sempre segundo o direito brasileiro, que, então, é expressamente consultado como estatuto contratual ou, simplesmente, como lex fori, sem qualquer justificativa. Parece que nos últimos casos a admissibilidade da exceção arbitral é qualificada implicitamente como problema processual. As diferentes decisões individuais serão reproduzidas, a seguir, em seqüência cronológica.

86. Em parte já havia sido substituído por códigos processuais de diferentes estados, nota supra 49 .

87. Trib. Dist. Fed. 23-04-1952, Diário da Justiça de 25-08-1955, Jurispr. pág. 2.945 (contrato de arqi.iteto); Trib. São Paulo, 22-10-1959, Rev. Trib. 293, pág. 263 (contrato social): ver também 17-12-1959 Rev. Trib. 296. pág. 41.0 (contrato de formulário), e 02-12-1952, Rev. Trib. 208, pág. 194 (testamento). A exceção de incompetência foi baseada no art. 1.821

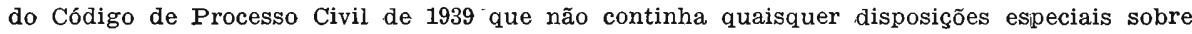
a exceção arbitral.

88. Ver o resumo sobre jurisprudencia em Alexandre de Paula, Código de Processo Civil anotado, vol. 4, 1977, pág. 376 e seg. Comp. também Trib. Santa Catarina, 02-07-1951, Rev. Forense 143, pág. 351; Trib. Dist. Fed., 11-04-1957, Repertório enciclopédico do direitu brasileiro, vol. 30 , pág. 37 .

89. Trib. São Paulo, 08-06-1962, Rev. Trib. 334, pág. 194 (contrato social), confirmado por 16-11-1962, Rev. Trib. 361, pág. 136; 16-05-1963, idem 360, pág. 198 (contrato de engenheiro); T. Alç. São Paulo, 05-08-1971, idem 434, pág. 159 (contrato social) com voto contra.

90. Ver dentre as decisões judiciais T. Alç. São Paulo, 02-10-1974, Rev. Trib. 470 , pág. 150 (contrato social); 07-08-1974, idem 472, pág. 127 (contrato social) com voto contra; 0r-03-1978, Rev. Trib. 513, pág. 170 (contrato social); outras decisões em Edson Prata, Repertório de Jurisprudência do Código de Processo Civil, vol. 17, 1978, pág. 5.565 e seg.

91. Carvalho Santos (nota 21), pág. 30 e seg.; Valladão (nota 20) pág. 215; semelhante Barros Leães (nota 20), pág. 421 e seg., 423. Comparar também Ascarelli/Sciascia (nota 65), pág. 206 e seg.

92. Rev. Sup. Trib. 66, pág. $3=$ Rev. Dir. 73 , pág. $145=$ Rev. Forense 41, pág. 455 = Pandectas Brasileiras 2, 192\%, II pág. 447. 
C. Dist. Fed. 26-7-1923, Société Générale d'Entreprises au Brésil v. United States Steel Products Company ${ }^{92}$ :

A ré belga e a autora norte-americana, ambas operando no Brasil, haviam celebrado aqui um contrato de compra de manganês, no qual fora previsto, para eventuais litígios, um tribunal de arbitragem em Londres. Face à ação proposta no Brasil, a ré fez valer a exceção da cláusula de arbitragem, vencendo na primeira instância ${ }^{93}$. O tribunal de apelação, a princípio, reconheceu esta sentença, declarando porém, em face de recurso, a cláusula arbitral sem efeito, em sua mui comentada decisão tomada em plenário ${ }^{94}$. Como motivação referiu-se ao Decreto $\mathrm{n}^{\circ} 3.900$ de 1867 e ao art. 13 da lei de introdução de 1961, que subordinam obrigatoriamente ao direito brasileiro e, conseqüentemente, à jurisdição brasileira, os contratos celebrados no Brasil ou a serem cumpridos no Brasil.

\section{Dist. Fed. 29-7-1927, Herdes v. Werkspoor ${ }^{95}$ :}

A autora havia assumido a representação geral no Brasil para a ré holandesa. $O$ contrato, que servia de base, continha uma cláusula de arbitragem, segundo a qual como árbitros só podiam ser nomeadas pessoas residentes e domiciliadas na Holanda. Após rescisão do contrato pela ré, a autora fez valer pretensões decorrentes das relações contratuais perante tribunais brasileiros. A exceção de arbitragem foi rejeitada nas duas instâncias com motivação semelhante ao caso anterior ${ }^{96}$.

Trib. Rio Grande do Sul 18-9-1940, J. Henry Schröder \& Cia. v. Hamburg-Südamerikasche-Dampfschiffahrts-Gesellschaft ${ }^{97}$ :

No início da Segunda Guerra Mundial o banco queixoso, com sede em Londres, havia arrestado o navio alemão "Montevideo" no porto de Rio Grande do Sul por causa de uma hipoteca sobre o navio. No seguinte processo executivo, a ré alemã, entre outras coisas, reportou-se a uma cláusula contratual que previa a decisão de litígios pelo tribunal de arbitragem da Câmara de Comércio Internacional. A princípio, a competência dos tribunais brasileiros foi admitida, mas rejei-

93. J. Dist. Fed. 10-09-1920, Rev. Forense 35, pág. 234. O juiz via na cláusula arbitral, em contraposição à interpretação dominante do Decreto no 3.900 de 1867, uma promessa obrigatória; ver também a sua decisão posterior de 26-08-1922, Rev. Forense 40, pág. 397 (nota 81).

94. A decisão resultou em uma discussão pública nos jornais entre os juízes participantes; comp. Pandectas Brasileiras 2, 1927, II, pág. 455 e seg., tendo influenciado a evolução da jurisprudência brasileira de forma decisiva.

95. Rev. Dir. 85, pág. 548.

96. Aqui também a competência dos tribunals brasileiros foi considerada imprescindivel, com referência aos artigos 13 e 15 da lei de introdução de 1916; opinião crítica contra esta decisão Valladão (nota 4) pág. 114.

97. Rev. Trib. 134, pág. $274=$ Rev. Forense 84, pág. 686; confirmada pelo Sup. Trib. Fed. 22-09-1941, Arch. Jud. 62, pág. 119. 
tada na instância de apelação, com a alegação casual de que o credor poderia recusar uma eleição de foro realizada a seu favor. A questão da arbitragem em si não foi discutida ${ }^{98}$.

Trib. São Paulo 31-3-1943, Knowles \& Foster v. Misuraca ${ }^{99}$ :

A ré havia vendido à autora vários lotes de farinha de trigo enviando-os para a Inglaterra, onde, quando da verificação, foram constatadas certas diferenças em peso e qualidade. Face à ação proposta no Brasil, a ré se reportou a uma cláusula contratual segundo a qual, em caso de litígio, as partes deveriam convocar um tribunal de arbitragem. Esta objeção foi declarada pelas duas instâncias como sendo irrelevante, já que um tribunal de arbitragem não havia sido convocado e a cláusula, em si, não era válida.

Sup. Trib. Fed. 2-6-1967, Insubra S.A. Intercomercial Sueco-Brasileira v. Büromaschinen-Export G.m.b.H. ${ }^{100}$ :

A autora trabalhava para a ré, uma firma de comércio exterior da RDA ou República Democrática Alemã na qualidade de comissionada. O contrato de comissão incluía uma cláusula de arbitragem a favor do tribunal de arbitragem de comércio exterior da RDA. Respondendo à ação de perdas e danos por inadimplento contratual, a ré levantou exceção arbitral, que, no entanto, foi refutada em todas as instâncias. A cláusula de arbitragem ofereceria apenas um direito à conclusão do contrato de arbitragem e, eventualmente, uma reivindicação de indenização, não podendo, porém, excluir a competência das cortes brasileiras ${ }^{101}$.

Trib. São Paulo 3-10-1967, Neptúnia Sociedade Marítima e Comercia] Ltda. v. Agência Marítima Triton Ltda. ${ }^{102}$ :

A autora reivindicava da ré, que representava os interesses de armadores estrangeiros no Brasil, a indenização de taxas portuárias, oriundas do descarregamento de um navio. No contrato de frete, que serviu de base, foi previsto um processo arbitral em Nova Iorque; a autora não havia respondido a uma citação pertinente. Em vista desta cláusula de arbitragem, o juiz da $1^{\text {a }}$ instância se declarou incompetente. A sua decisão, no entanto, foi revogada, já que a cláusula de arbitragem, no caso de inadimplência, só concede um direito de indenização mas nenhuma exceção perante um tribunal ordinário.

98. Durante a guerra os tribunais brasileiros confirmaram a sua competência em casos similares, sobrepondo-se também ao art. 482 C. Com., que permite o confisco de navios estrangeiros meramente por causa das obrigações contraídas no Brasil; comp. em Waldemar Ferreira (nota 11), Vol. 13, págs. $730-735_{\text {, }}$ e Garland (nota 18), pág. 86 nota 349.

99. Rev. Trib. 145, pág. $633=$ Rev. Forense 98, pág. 112 (princípio).

100. Rev. Trim, Jur. 42, pág. 212.

101. Esta competência fundamentada no local de execução brasileira (Art. 12 da lei de introdução 1942) foi considerada absolutamente imprescindível pelo juiz de primeira instância.

102. Rev. Trib. 390, pág. 180. 


\section{c) Conclusões}

Segundo o direito brasileiro, cláusulas de arbitragem, em princípio, não são executáveis, também em casos internacionais ${ }^{103}$. Com relação à República Federal da Alemanha, no entanto, deve ser observado o Protocolo de Genebra sobre cláusulas arbitrais de 1923 que, segundo a concepção predominante, se sobrepõe ao direito nacional ${ }^{104}$. $\mathrm{Na}$ verdade, porém, o protocolo até hoje não foi aplicado na jurisprudência ${ }^{105}$. Portanto, não se pode afirmar, com certeza, se um tribunal brasileiro aceitaria uma cláusula de arbitragem como vinculativa com base no referido protocolo.

$\mathrm{Na}$ elaboração de um contrato é preciso, pois, levar em consideração, desde o princípio, a possibilidade de que, apesar de convencionada uma cláusula de arbitragem, uma ação no Brasil será admitida e a exclusão de arbitragem rejeitada. E verdade que, teoricamente, em algumas decisões, perante uma tal violação da cláusula de arbitragem, uma ação de perdas e danos pode ser considerada viável; na prática, porém, nestes casos, já a comprovação de danos poderia acarretar dificuldades consideráveis. $\mathrm{Na}$ literatura encontra-se, por isso, a recomendação de se acordar uma cláusula penal para o caso de ser violada a cláusula de arbitragem ${ }^{106}$.

Por outro lado, considerando-se a prática arbitral acima exposta, parece ser perfeitamente viável a realização de um processo de arbitragem no Brasil, com base na cláusula arbitral ${ }^{107}$. Neste caso, porém, é imprescindivel observar-se que antes seja celebrado um contrato arbitral válido quanto às formalidades, que especifique o objeto de litígio e os árbitros. A ausência de um tal contrato de arbitragem implica, segundo a jurisprudência, a nulidade da decisão arbitral, mesmo no caso de as partes participantes terem se submetido tacitamente ao juízo arbitral ${ }^{108}$. Para tanto não basta o acordo de que os árbitros devam ser nomeados por uma instituição de arbitragem, nem tampouco será sanado o vício do contrato de arbitragem através da argumentação do mérito junto ao tribunal de arbitragem ${ }^{109}$. Finalmente, o processo de arbitragem também pode ser realizado no estrangeiro; neste caso dever-se-ia analisar mais detalhadamente os requisitos para a homologação da sentença arbitral no Brasil.

103. Até que ponto as determinações legais citadas nas notas de rodapé 52, 64 contêm uma exceção ainda não foi decidido judicialmente até hoje. Sobre direito marítimo ver nota supra 51.

104. Nota 20 supra.

105. Nas decisões supracitadas (notas 92-102) o protocolo não foi levado em consideração de modo algum, sendo na maioria dos casos, inaplicável por motivos de tempo ou de espaço.

106. R. Nunes (nota 77), pág. 19; Silvio Rodrigues, Direito Civil, vol. 2, 8p edição.

1978, pág. 275. Comp. também Moser (nota 66), pág. 31 e 33 e segs.

107. Comp. acima II 2 b.

108. Trib. São Paulo, 16-05-1978, Rev. Trib. 514, pág. 82.

109. Em contrário Marotta Rangel (nota 20), pág. 33, 36 e seg., 43. A sua opinião, no entretanto, não encontra respaldo na jurisprudência e na lei (ver artigos 1.074 II, 1.100 I do Código de Processo Civil). 


\section{Homologação de decisões arbitrais estrangeiras}

Inicialmente considerava-se a homologação e execução de decisões arbitrais estrangeiras como objeto de cartas rogatórias. Relata-se, nesse contexto, que no ano de 1846, uma decisão arbitral francesa chegou à execução ${ }^{110}$ a pedido da legação francesa no Brasil. Pouco tempo depois, ainda no século XIX, a homologação de decisões arbitrais foi regulamentada legalmente. Esta regulamentação representou o ponto de partida para a posterior evolução do direito.

\section{a) Regulamentação legal}

Já o Decreto $\mathrm{n}^{\circ} 6.982$ de 1878 tratava da execução de decisões judiciais e sentenças arbitrais estrangeiras ${ }^{111}$. Uma nova regulamentação ampla efetuou-se por meio da Lei $\mathrm{n}^{\circ} 221$ de 1894, que, em princípio, transferia ao Supremo Tribunal a homologação de decisões estrangeiras ${ }^{112}$. As disposições normativas foram então coletadas na "Consolidação das Leis referentes à Justiça Federal" de $1898{ }^{113}$, que durante um longo período de tempo representou a base para a homologação de decisões estrangeiras ${ }^{114}$. As disposições pertinentes no todo foram adotadas, praticamente inalteradas, pela legislação posterior ${ }^{115}$, sendo sempre assumidas pelos diferentes regimentos internos do Supremo Tribunal Federal 11.6. O Código de Processo Civil de 1973 limita-se, no art. 483, a deixar a homologação del sentenças estrangeiras, em geral, ao Supremo Tribunal e se reporta, daí por diante, no que diz respeito aos requisitos ${ }^{117}$, ao regimento interno do mesmo. A decisão sobre a homologação compete, desde 1977, ao presidente do Tribunal 118. A execução deve ser levada a cabo em seguida junto ao tribunal brasileiro competente.

110. Pimenta Bueno, Direito Internacional Privado, 1863, pág. 143 e seg.. 145.

111. Decreto no 6.982 de 27-07-1878, Col. 1878 pág. 445; complementado pelo Decreto no 7.777 de 27-07-1880, Col. 1.880, pág. 380. Ver Almeida Oliveira, A lei das execuções, 1915, pág. 8276 e seg.

112. Lei no 221 de 20-10-1894, art. 12 \& 4; ver Clóvis Bevilacqua (nota 80). art. 16 Intr. Obs. 1.

113. Consolidação, Parte V, artigos 7 e seg.; ver Tavares Bastos, Decreto no 3.084 de 05-11-1898 ou Consolidação das leis referentes à justiça federal, Vol. 2, 1915, pág. 357 e seč.

114. A Introdução de 1916 não continha regras próprias sobre a execução de decisões estrangeiras, referindo-se, no entanto, às "condições que a lei brasileira fixar" (art. 16), e desta forma à Consolidação de 1898; comp. em Carvalho Santos (nota 21), vol. 1. 1934, pág. 195 e seg.

115. Código de Processo Civil 1939, artigos 791 e seg., Lei de introdução 1942, art. 15,

116. Ver agora a edição em vigor do regimento interno no Código de Processo Civil de 1979 de Th. Negrão. 89 edição, 1979, pág. 611 e seg. Os artigos 210-217 pertinentes se encontram também em Valladão, Direito Internacional Privado, Material de classe. 10 edição, 1979, pág. 225 e seg.

117. Críticas por parte de Valladão (nota 20), pág. 188 e seg.

118. Art. 120 do Regimento Interno modificado com base na Emenda Constitucional ne 7 de 13-04-1977, (art. $119 \S 3$ d). Contra a decisão do Presidente é cabivel agravo que no caso de seu não conhecimento será submetido ao julgamento do plenário (art. 300 do Regimento Interno do Supremo Tribunal Federal). Com relação à revisão do processo ver Sup. Trib. Fed., 16-06-1976, Rev. Trim. Jur. 80, pág. 1. 
A homologação de decisões estrangeiras depende, segundo as disposições mencionadas, dos seguintes requisitos:

- A sentença deve ter transitado em julgado e ser exequível no país de origem ${ }^{119}$.

- Assim é necessário que a sentença tenha sido proferida por juíz competente, após citação das partes ou verificação de sua revelia, consoante os preceitos legais; também, no caso destes requisitos, o que, em princípio, decide é o direito do país de origem ${ }^{120}$.

- A decisão não deve atentar contra a ordem pública brasileira; assume-se, entre outras coisas, uma tal violação quando existe uma jurisdição exclusivamente brasileira ou quando as formalidades da citação são incompatíveis com a "lex fori" brasileira ${ }^{121}$.

- A sentença deve estar autenticada pelo Cônsul do Brasil e acompanhada de uma tradução juramentada (oficial) ${ }^{122}$.

Estes princípios valem, em geral, também para a homologação de laudos arbitrais. Já o Decreto $\mathrm{n}^{\circ}$ 6.982, de 1878, vinculava a homologação, neste caso, à homologação judicial do laudo arbitral no país de origem; este regulamento também foi incluído na "Consolidação" de $1898^{123}$. Em contraposição, todas as leis posteriores, inclusive o art. 483 do Código Processual Civil vigente se referem, nessa matéria, apenas à homologação de sentenças dos tribunais estrangeiros. De acordo com a opinião reinante, entendem-se aqui também sentenças arbitrais homologadas em juízo, ou seja, decisões judiciais pelas quais uma sentença arbitral foi confirmada ou declarada exequível, estando sujeitas, portanto, ao processo de homologação normal ${ }^{124}$. Sentenças arbitrais estrangeiras que não foram confirmadas judicialmente no país de origem não poderão ser homologadas posteriormente pelo presidente do Supremo Tribunal Federal ${ }^{125}$.

119. A executoriedade provisória de uma sentença alemã não basta, comp. Sup. Trib. Fed. 03-11-1978, Rev. Trim. Jur. 89, pág. 33.

120. Neste sentido expressamente a Consolidação de 1898, Art. 8 e o Código de Processo Civil de 1939, art. 791. Também as disposições vigentes na lei de introdução de 1942, art. 15 e no RISTF de 1970, art.212, que não contêm qualquer referência expressa com relação ao direito do país primário, são interpretadas neste sentido, Valladão (nota 20). pág. 199 e seg.

121. Ver Valladão idem: Pontes de Miranda (nota 41), vol. 10, 1960, pág. 54 Mais detalhes ref. a estes requisitos na nota 150 adiante, 155.

122. Comp. Samtleben, RabelsZ 30 (1966) pag. 465.

123. Decreto ne 6.982 de 1978, art. 13 (nota 111); Consolidação, art. 14 (nota 113)

124. Amilcar de Castro, Direito Internacional Privađo, 3a edição, 1977, pág. 526; Campos Batalha, Tratado de Direito Internacional Privado, vol. 2, 2 edição 1977, pág. 453, 456, H. Accioly, Bol. Soc. Bras. Dir. Int. 8 (1952), pág. 112 e seg.; Barros Leães (nota 20), pág. 217.

125. De acordo com uma opinião defendida na literatura, estas sentenças arbitra1s devem ser tratadas como transações de direito privado, ibidem Valladão. 
b) Jurisprudência

Até o ano de 1940 não havia decisões brasileiras dizendo respeito diretamente à homologação de laudos arbitrais estrangeiros ${ }^{126}$. $\mathrm{Na}$ verdade a jurisprudência considerava, naquela época, a convenção de tribunais de arbitragem estrangeiros de todo improcedente, na medida em que o lugar de execução ou o domicílio da ré era o Brasil e classificava, neste contexto, a execução de uma tal sentença arbitral no Brasil como atentado contra a ordem pública ${ }^{127}$. Isto correspondia à prática em vigor antigamente que, nestes casos, inferia dos arts. 13 $\S 1$ e 15 da Introdução de 1916 uma competência exclusiva dos tribunais brasileiros ${ }^{128}$. Somente com a entrada em vigor do Código de Processo Civil de 1939 e da Lei de Introdução de 1942 esta situação sofreu uma mudança. Em conseqüência, diversos laudos arbitrais estrangeiros foram reconhecidos pela jurisprudência.

Sup. Trib. Fed. 22-04-1941, Alves Vilela v. Dannemann ${ }^{129}$ : Aqui não se tratava de um laudo arbitral estrangeiro propriamente dito, mas sim de um parecer dado por peritos. O algodão fornecido pela autora à ré havia sido revendido pela mesma na Inglaterra, onde, em um exame realizado por peritos, ficou constatada que quantidades consideráveis faltavam. A sentença baseada neste exame e proferida por um tribunal brasileiro foi contestada pelo Supremo Tribunal com a alegação de que houve violação das disposições sobre a homologação de decisões estrangeiras. O Supremo Tribunal rejeitou a petição (recurso) como inepta em se tratando de uma instrução (princípio de prova), cuja realização está sujeita à respectiva legislação local.

Sup. Trib. Fed. 02-05-1945, Frank Feher \& Co. v. Cia. Industrial, Comercial e Agrícola ${ }^{130}$ :

A autoria inglesa havia comprado da ré brasileira óleo de algodão para fornecimento a Liverpool, realizando, por isso, com a ré mais tarde um processo arbitral na Inglaterra. O laudo arbitral que condenava a ré à indenização de danos por inadimplência havia sido confirmada via recursal por tribunal de Estado. A requerimento da autora, o Supremo Tribunal brasileiro declarou esta sentença exeqüível no Brasil: as partes haviam se submetido eficazmente à jurisdição dos tribunais ingleses. Da mesma forma, a ordem pública brasileira não havia sido ofendida, já que a jurisdição dos tribunais brasileiros, funda-

126. Ainda em 1952 um parecer elaborado pelo Ministério do Exterior brasileiro, em resposta a uma pergunta apresentada por um Professor de Colônia, chegou à conclusão de que o Supremo Tribunal Federal até então não havia tratado da homologacão de laudos arbitrais estrangeiros. H. Accioly (nota 124), pág. 115 e seg.

127. Ver as decisões supra sob nota de rodapé 92,95 e seg.

128. Comp. as comprovações em Garland (nota 18), pág. 89.

129. Rev. Forense 8, pág. 123.

130. Arch. Jud. 75, pág. 409. 
mentada no local de execução ou domicílio da ré, poderia ficar invalidada segundo art. 12 da Nova Lei de Introdução* de $1942^{131}$.

Sup. Trib. Fed. 04-05-1959, M. Augueso \& Co., Inc. v. Aparício \& Cia. Ltda. ${ }^{132}$ :

A autora americana havia importado da ré brasileira cera de carnaúba e por causa de sua má qualidade exigido indenização. Basendo-se em uma cláusula arbitral contida no contrato, a autora obteve um laudo arbitral da "American Arbitration Association", em Nova Iorque, que condenou a ré ao pagamento de US\$ 2800; a ré não integrou este processo. A sentença arbitral foi declarada exeqüível por um tribunal de Nova Iorque.

A sentença foi homologada pelo Supremo Tribunal Federal brasileiro, visto que a jurisdição convencionada do tribunal de arbitragem de Nova Iorque não atentava contra a ordem pública brasileira ${ }^{133}$. Com o seu recurso a ré contesta não ter sido citada para o processo em Nova Iorque; esta contestação, no entanto, não foi acolhida pelo Supremo Tribunal, que confirmou a homologação, referindo-se à cláusula de arbitragem e ao art. 12 da Lei de Introdução de 1942.

Nestas sentenças o local de execução ou o domicílio da ré no Brasil não mais era considerada impedimento para a homologação de uma sentença arbitral estrangeira. Isto correspondia a um conceito modificado que não mais interpretava como exclusiva a jurisdição dos tribunais brasileiros, agora consolidada pelo art. 12 da Lei de Introdução de $1942^{134}$.

Conseqüentemente a escolha de um tribunal de arbitragem estrangeiro e a execução de uma sentença arbitral no Brasil não violavam, em princípio, a ordem pública brasileira ${ }^{135}$. Parece que na jurisprudência e na prática brasileira, as sentenças mencionadas passaram despercebidas. Somente dez anos depois foi feita uma nova tentativa para executar sentenças arbitrais estrangeiras no Brasil; a aprovaçầo judicial, desta vez, era requisito primordial. Assim, o Supremo 'ribunal Federal demonstrou claramente em três decisões consecutivas que laudos arbitrais estrangeiros, sem confirmação judicial no país de origem, náo podiam ser liberados (admitidos) para execução no Brasil.

* Lei de Introdução ao Código Civil.

131. A argumentação também deixa perceber a influência do Código Bustamante quo no art. 318 permite expressamente a prorrogação internacional; comp. quanto à decisão Samtleben (nota 28), pág. 159 nota 187.

132. Rev. Trim. Jur. 10, pág. 409. pág. 51.

133. Sup. Trib. Fed. 04-08-1958 (não publicado); ver Straus, Bus. Lawyer 21 (1965/66),

134. Comp. provas em Valladão (nota 20), pág. 139 e seg.

135. A questão da "ordre public" foi apresentada em um processo perante o Supremo Tribunal sobre a homologação de duas sentenças arbitrais, que envolviam a abdicação $e$ a sucessão do primaz de uma dinastia; comp. Redig de Campos, Rev. Forense 166 (1956) pág. 117, 120 e segs.; desconhece-se o final do processo. 
Sup. Trib. Fed. 20-03-1969, Panchaud Fréres v. Cia. Paulista de Exportação ${ }^{136}$ :

Trata-se de uma carta rogatória de um processo suíço, no qual uma firma suiça solicitava seqüestro contra seus vendedores brasileiros de milho com base em uma sentença arbitral da "London Corn Trade Association". O presidente do Supremo Tribunal Federal havia, de início, rejeitado o pedido de citação dos participantes brasileiros já que os mesmos só poderiam ser acionados no Brasil e, além do mais, a sentença arbitral não havia sido homologada (confirmada) judicialmente. Por outro lado, o Supremo Tribunal no procedimento recursal acolheu a petição. Embora uma execução da sentença arbitral, não confirmada judicialmente, seja impossível no Brasil, a notificação da citação para o processo pendente na Suíça nåo implicaria uma execução ${ }^{137}$.

Sup. Trib. Fed. 03-06-1970, Northern International Co., Inc. v. Curtume Kern-Mattes S.A. ${ }^{138}$ :

A autora norte-americana, que havia comprado da ré brasileira no Rio Grande do Sul um lote de couro, pretendia a homologação de uma sentença arbitral da "Inter-American Commercial Arbitration Commission" em Nova Iorque, pela qual a ré havia sido condenada ao pagamento de US\$ 1.100 com base na cláusula arbitral convencionada. O Supremo Tribunal brasileiro negou a homologação da sentença arbitral não confirmada judicialmente, em se tratando de uma mera decisão de uma organização privada sem qualquer participação do Estado. Na verdade, esta forma de resolução de um litígio corresponde a uma tendência difundida a favor da arbitragem no intercâmbio comercial internacional ${ }^{139}$. De acordo com o direito brasileiro, porém, no que diz respeito à garantia de instância (via legal) do art. 153, $\S 4$ da Constituição, torna-se imprescindível, em todo o caso, a confirmação judicial da sentença arbitral ${ }^{14 a}$. Com relação a uma posição do direito americano, algo divergente, a autora prescindiu da indicação da prova ${ }^{141}$.

136. Rev. Trim. Jur. 52, pág. $299=$ Rev. Forense 235, pág. 64 .

137. No que tange a disputâ, se um pedido de citação pode ser efetrado no Brasil apesar de a decisão estrangeira correspondente não ser homologada, ver provas em Samtleben, RabelsZ 44 (1980) pág. 274 nota 107 e seg.

138. Rev. Trim. Jur. 54, pág. 714.

139. Neste contexto encontra-se uma referência casual sobre os tratados de Genebra de 1923 e 1927, Rev. Trim. Jur. 54, pág. 715.

140. Comparar as notas de rodapé supra 39, 42, 58.

141. Dấ não pode ser deduzido que o tribunal julgaria a necessidade da confirmação judiciária realmente de acordo com o direito do Estado de origem. Antes aqui lhe era dado um meio fácil de contestar este argumento obviamente apresentado no processı; comparar Samtleben, A aplicação do direito estrangeiro em DIP, 1966, pág. 61, 63. 
Sup. Trib. Fed. 18-11-1971, Otraco S.A. v. Cia. Nacional de Óleos Vegetais ${ }^{142}$ :

A autora suíça havia comprado da ré brasileira sementes de rícino fazendo valer pretensões de indenização por causa de acondicionamento deficiente. Uma decisão arbitral da "Cattle Food Trade Association" em Londres condenou a ré ao pagamento de 40.000 francos franceses. A homologação deste laudo arbitral no Brasil, como no caso precedente, foi negada pelo Supremo Tribunal Federal referindo-se à falta de confirmação judicial. Além disso, não havia sido apresentada a prova de competência e citação.

Estas decisões, no que diz respeito ao resultado (efeito), fizeram com que a homologação de sentenças arbitrais estrangeiras no Brasil se tornasse novamente incerta. Foi necessária mais uma década antes que o Supremo Tribunal Federal tivesse outra oportunidade para se pronunciar sobre este assunto. Em suas decisões (jurisprudência) mais recentes, o Supremo Tribunal Federal definiu finalmente os princípios para a homologação de sentenças arbitrais estrangeiras. $\mathrm{O}$ Supremo Tribunal Federal declara que, em princípio, não existem quaisquer impedimentos para a homologação no Brasil de sentença arbitral estrangeira confirmada judicialment.e A homologação, no entanto, depende de a ré no Brasil ter sido citada regularmente por vias legais.

Sup. Trib. Fed. 08-11-1979, Centrofin S.A. v. La Pastina S.A. ${ }^{143}$ :

A autora suíça, que havia adquirido arroz da ré brasileira, tinha convencionado no contrato de compra "Hamburger freundschaftliche Arbitrage" e obtido, posteriormente, uma decisão arbitral correspondente, referente a uma reivindicação de indenização no valor de US\$ 25.000. No processo de arbitragem, a ré havia sido representada por uma firma de Hamburgo. A decisão arbitral havia sido declarada exeqüível pelo $\mathrm{LG}^{*}$ de Hamburgo; a ré, a despeito de ter sido citada para este processo por meio de carta rogatória, não atendeu ao chamado. A homologação da decisão arbitral no Brasil foi detalhadamente fundamentada pelo Presidente do Supremo Tribunal Federal ${ }^{144}$. A competência da Corte de arbitragem de Hamburgo seria eficaz de acordo com o direito alemão (!), não havendo uma competncia exclusiva por parte das cortes brasileiras. A ré havia sido citada legalmente para o processo perante o LG de Hamburgo, não podendo mais questionar eventuais irregularidades na citação ao processo de arbitragem,

* Landgericht $=$ Tribunal Regional.

142. Rev. Trim. Jur. 60, pág. 28.

143. Rev. Trim. Jur. 92, pág. 515.

144. Pres. Sup. Trib. Fed. 30-06-1979, Diário da Justiça de 27-08-19-9, Jurispr. ṕág. $6.285=$ Rev. Trim. Jur. 91, pág. 48; ver com relação a esta decisãa Rosenn, Am. J. Com. L. 28 (1980) pág. 498 e sgs. 
já que no referido processo ela havia sido representada e no processo judicial subseqüiente não teria censurado esta irregularidade. A ordem pública brasileira não fora violada, pois a decisão arbitral tinha obtido convalidação forense equiparando-se, com isto, a uma sentença estrangeira ${ }^{145}$.

Esta decisão do presidente foi confirmada pelo Supremo Tribunal Federal e um exame formal e textual da decisão arbitral foi categoricamente rejeitada.

Pres. Sup. Trib. Fed. 14-12-1979, Compagnie Noga S.A. v. Fasko S.A. ${ }^{1 / 46}$ :

A autora suiça reivindicava a homologação de uma sentença arbitral inglesa pela qual a ré brasileira havia sido condenada ao pagamento de US\$ 120.000. A sentença arbitral havia sido confirmada pelo High Court (Q.B.). A citação para os dois processos havia sido entregue ao Consulado Geral do Brasil em Londres; a ré não havia comparecido ao processo perante o High Court. O Presidente do Supremo Tribunal Federal opinou de modo desfavorável à homologação pelo fato de a citação para o processo judicial não ter sido apresentada através de uma carta rogatória formal e esta irregularidade não ter sido sanada por meio de defesa do fundo (defesa do mérito).

Pres. Sup. Trib. Fed. 19-12-1979. Société Nouvelle D'Affétement v. Caldas Ltda. ${ }^{147}$ :

A autora francesa havia encarregado a ré brasileira de embarque de madeira para a Algéria. Com base em uma cláusula de arbitragem contida no contrato de fretamento, um tribunal de arbitragem de Londres havia condenado a ré por violação de contrato ao pagamento de 62.000 libras esterlinas. A sentença arbitral havia sido confirmada pelo High Court (Q.B.). Para o processo perante o High Court a ré havia sido citada por meio de carta e através de encarregados no Brasil, não tendo porém comparecido. O presidente do Supremo Tribunal Federal salientou no processo homologatório que, com base no preceito contratual vinculativo, a Corte de arbitragem e o High Court eram competentes de acordo com o direito inglês e que também a forma de citação teria, em princípio, que ser considerada segundo o direito inglês. A ordem pública brasileira, porém, exige que, conhecendo-se o endereço da ré, esta seja citada por meio de carta rogatória entregue por um oficial de justiça; esta irregularidade só poderia ser sanada por meio de defesa de fundo (argumentação do mérito).

145. Face ao argumento de que a garantia da via judicial do art. 153 § 4 da Constituição de 1969 contradiga a homologação dả sentença arbitral, o Presidente se referiu, entre outras coisas, à equiparação de laudos jidiciais e sentenças arbitrais estrangeiras na Convenção de Montevidéu de 1979 (acima I 2 b).

146. Rev. Trim. Jur. 92, pág. 1.074.

147. Rev. Trim. Jur. 92, pág. 1.077. 
De acordo com esta jurisprudência deve-se considerar, como objeto da homologação, a decisão judicial pela qual a decisão arbitral foi confirmada. Torna-se necessário, portanto, que a ré seja citada regularmente para este processo judicial ${ }^{148}$. E verdade que, teoricamente, neste caso parte-se do princípio segundo o qual a citação se orienta pelo direito do país do juízo. Na prática, porém, sabendo-se que o domicílio da ré é no Brasil, exige-se que a citação seja realizada aqui por meio de uma carta rogatória formal ${ }^{149}$. A jurisprudência mais recente defende, de modo inequívoco que, neste caso, qualquer outro tipo de citação representa um atentado contra a ordem pública brasileira ${ }^{150}$; isto também se aplica principalmente à citação direta feita através de representações diplomáticas ${ }^{151}$. Esta irregularidade só pode ser sanada quando a ré, a despeito da ausência de citação ou, apesar de citação insuficiente, tenha-se submetido ao processo ${ }^{152}$ ou, ela própria, posteriormente se refira a esta decisão ${ }^{153}$.

\section{c) Conclusões}

Hoje em dia, a homologação de sentenças estrangeiras no Brasil pode ser considerada como assegurada em larga escala, apesar de ser preciso talvez contar com um processo moroso ${ }^{154}$.

A jurisdição do tribunal de arbitragem estrangeiro é respeitada sempre que convencionada de acordo com o direito vigente no país

148. Hoje em dia dedica-se maior atenção a este ponto do que nas decisões antigas (notas de rodapé supra 130, 132). Em contrapartida, a citação para o processo arbitral não é tão importante. Este ponto foi devidamente salientado pelo procurador geral nos dois processos mais recentes (acima nota de rodapé 146 e seg.)

149. Também a carta rogatória no processo de exequatur deve ser confirmada pelo presidente do Supremo Tribunal Federal (art. 218 e segs. do RISTF) e cumprida antes da fromulgação da decisão estrangeira, Sup. Trib. Frił., 29-04-1970, Rev. Trim. Jur. 54, páł. EG1. 150. Comp. da prática do Supremo Tribunal Federal com relação à citação por meio de notificação públìca: 20-10-1958, Rev. Trim. Jur. 8 , pág. 275; 19-11-1979, idem 192, pág 522; através de carta registrada: 14-11-1958, idem 9, pág. 263; 04-04-1974, idem 87, pág. 384;

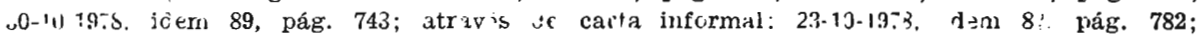

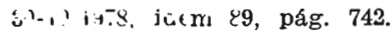

151. Comp. Mendonça Pais, Scientia Juridica 4 (1955) pág. 359 è sgs. A citação através da representação no exterior segundo \$ 199 ZPO a princípio foi considerada no Brasil sem efeito. Sup. Trib. Fed. 20-10-1958, Rev. Trim. Jur. 8, pág. 276, mais tarde, porém, aceita. 25-07-1960, idem 14, pág. 272; a prática mais recente volta a se basear nas decisões antigas, 04-06-1979, idem 90, pág. 777 (e decisões supracitadas notas de rodapé 146 e sg.).

152. Supr. Trib. Fed., 14-11-1958 (nota 150); 06-08-19-9, Rev. Trim. Jur. 91, pág. 56.

153. Através de requerimento de homologação: Pres. Sup. Trib. Fed. 04-06-19779 (nota 151); 17-11-1978, Rev. Trim. Jur. 90 pág. 14; 04-06-1979, idem 91, pág. 419; por meío de emprego em outro processo: 04-06-1979, idem 90, pág. 780.

154. Entre o requerimento de confirmação judiciária da sentença arbitral no país de origem e a homologação pelo STF brasileiro existem, às vezes, períodos de 4 ou de até 10 anos (ver o processo nas notas de rodapé 143, 147); críticas por parte de Rosenn (nota 144), pág. 499, 503 e sgs. - A transferência de decisão do exequatur para o presidente do tribunal pretende evidentemente servir para apressar o processo, uma vez que o recurso contra a sua decisão não possui efeito suspensivo (comp. acima nota 118). 
do processo de arbitragem ou fundada em defesa de mérito e os tribunais brasileiros não gozarem de jurisdição exclusiva ${ }^{155}$. A citação para o processo de arbitragem não é analisada em sentido formal; mesmo a homologação de uma decisão arbitral promulgada à revelia da ré em geral não é excluída ${ }^{156}$.

Contudo é imprescindivel que a ré tenha tido oportunidade suficiente para se defender ${ }^{157}$. Aliás a decisão arbitral não é examinada nem do ponto de vista formal, nem quanto ao seu conteúdo material, na medida em que não exista no caso concreto uma violação contra a ordem pública brasileira ${ }^{158}$.

Condição "sine qua non" para a homologação da sentença arbitral é, no entanto, que ela, no país de origem, tenha sido confirmada ou declarada exeqüivel por uma decisão judicial. É preciso considerar aqui que esta decisão, segundo a jurisprudência, representa o objeto propriamente dito da homologação; ela deve, portanto, preencher todos os requisitos dos quais depende a homologação de decisôes estrangeiras em conformidade com o direito brasileiro ${ }^{159}$. A competência do foro homologatório é dada regularmente na medida em que o tribunal de arbitragem por seu lado seja competente de acordo com o respectivo direito local. No entanto, de importância primordial é o fato de a ré no Brasil ser citada para o processo judicial estrangeiro por meio de uma carta rogatória formal. No caso de uma homologação judicial de uma sentença arbitral na Alemanha, estes seriam os passos que deveriam ser tomados hoje em dia ${ }^{160}$. Se, por outro lado, o processo de arbitragem for realizado em um terceiro país, cujo direito prevê possibilidades menos formais de citação, então a homologação da decisão arbitral no Brasil só será garantida quando a ré puder ser citada formalmente para o referido processo judicial ou então participe do mesmo.

155. Uma competência exclusiva das autoridades judiciais brasileiras existe de acordo com art. 89 do Código de Processo Civil de 1973 apenas com relação a imóveis situados no Brasil e a hērança. Além disso é afirmada uma competência exclisiva para as ações nas quais o estado brasileiro toma parte. Comp. Rosenn (nota 144), pág. 502 nota 14; contrário Marotta Rangel (nota 20), pág. 34.

156. Opinião divergente em Marotta Rangel (nota 20), pág. 39, 44, que se reporta à jurisprudência do STF; as sentenças publicadas, no entanto, não oferecem nenhum ponto de apoio (ver nota de rodapé supra 132).

15. Comp. no todo Valladão (nota 20) pág. 200; uma referência expressa feita a esta exigência é encontrada na decisão supra sob nota 144, pág. 6.287 e/ou 56

158. Valladão (nota 20 ), pág. 220 vê tal infração especialmente no caso de cláusulas arbitrais abusivas em contratos de adesão (ref. a $\$ 1.025$ inciso 2 do Código de processo civil alemão): também a decisão na nota 130 supra exige um "loyal play" (pág. 415).

159. Ver II 4 a) supra com relação aos requisitos formais para a homologação.

160. Ver as disposições correspondentes dos §§ 6, 13, ZRHO em Bülow/Böckstiegel, Intercâmbio Jurídico Internacional em matérias civis e assuntos comerciais, 1973 e sgs., 900,9 e segs., principalmente a nota de rodapé 49 . - Relativo à praxe antiga ver nota acima 151 e OLG Hamburg, 27-04-1926, IPRspr. 1926-27, n० 157. 